Cornell Law Library

Scholarship@Cornell Law: A Digital Repository

Cornell Law Faculty Publications

$11-15-2007$

\title{
Anti-Foreign-Suit Injunctions to Enforce Arbitration Agreements
}

John J. Barceló III

Cornell Law Library, jjb16@cornell.edu

Follow this and additional works at: http://scholarship.law.cornell.edu/lsrp_papers

\section{Recommended Citation}

Barceló III, John J., "Anti-Foreign-Suit Injunctions to Enforce Arbitration Agreements" (2007). Cornell Law Faculty Publications. Paper 87.

http://scholarship.law.cornell.edu/lsrp_papers/87

This Article is brought to you for free and open access by Scholarship@Cornell Law: A Digital Repository. It has been accepted for inclusion in Cornell Law Faculty Publications by an authorized administrator of Scholarship@Cornell Law: A Digital Repository. For more information, please contact jmp8@cornell.edu. 


\title{
CORNELL LAW SCHOOL
}

\section{LeGal Studies ReseArCh PAPER Series}

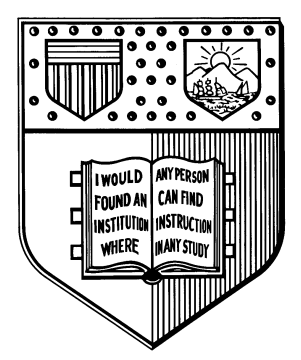

\section{Anti-Foreign-Suit Injunctions to Enforce Arbitration Agreements}

\author{
John J. Barceló III \\ Cornell Law School \\ Myron Taylor Hall \\ Ithaca, NY 14853-4901
}

Cornell Law School research paper No. 07-024

This paper can be downloaded without charge from:

The Social Science Research Network Electronic Paper Collection:

http://ssrn.com/abstract=1030403 
October 17, 2007

(Presented at Fordham Conference--June 18-19, 2007)

\section{Anti-Foreign-Suit Injunctions to Enforce Arbitration Agreements}

John J. Barceló III

W. N. Cromwell Professor of Law

Cornell Law School

An anti-foreign-suit injunction is controversial because it constrains judicial proceedings in another sovereign country. It does so indirectly by controlling the actions of private parties. The enjoining court in one country (F1) orders a private litigant before it to suspend or terminate a legal proceeding in another country (F2) on pain of sanctions that F1 will impose on the private party for disobedience. Although formally there is no direct interference with, or order addressed to, a foreign judicial power, as a practical matter the effect in the foreign jurisdiction can be substantial. If the enjoined party has assets in $\mathrm{F} 1$, or a thriving business there, or just attractive future business prospects in F1, it will not want to risk transgressing the F1 order. Thus, the litigant will comply and terminate (or not initiate) legal proceedings in $\mathrm{F} 2$. 
As is well known, civil-law jurisdictions generally find anti-foreign-suit injunctions offensive, even violative of international law. ${ }^{1}$ On the other hand common-law jurisdictions, especially courts in the UK and US, consider an anti-foreign-suit injunction appropriate under some circumstances. Although I agree with the view that courts should give considerable weight to "international comity" before issuing an anti-foreign-suit injunction and in general should use this remedy only sparingly, I argue in this essay that the remedy is appropriate and useful in a particular context.

That context arises where the parties have agreed to arbitrate disputes in F1 and have chosen F1 law to govern the arbitration agreement. In that case I argue an F1 court should have discretion to issue an antiforeign-suit injunction to enforce the arbitration agreement.

I would make room for one major exception-where there are relatively strong (and appropriately applicable) public policy considerations in the alternative forum (F2) for avoiding the arbitration agreement. Ordinary issues of fact finding or contract construction to decide, for

\footnotetext{
1 See judgment of the Oberlandesgericht [OLG] Düsseldorf [German Court of Appeal of Düsseldorf ] Jan. 101996 in Re the Enforcement of an English AntiSuit Injunction (quoted in relevant part in West Tankers, Inc. v. Ras Riunione Adriatica de Sicurta SpA, (2005) 2 Lloyd's Rep 257; (2005) 2 All E. R. (Comm) 240; 2005 WL 699582 (QBD (Comm Ct)). See also Emmanuel Gaillard, II Est Interdit d'Interdire: Réflexions sur l'Utilisation des Anti-Suit Injunctions dans l'Arbitrage Commercial International, 2004 Rev. Arb. at 47-62; Marco Stacher, You Don't Want to Go There-Antisuit Injunctions in International Commercial Arbitration, 23 ASA Bulletin, at 644 - 645 (2005). Cf. Emmanuel Gaillard, ed., ANTI-SUIT INJUNCTIONS IN INTERNATIONAL ARBITRATION (2005).
} 
example, whether an arbitration agreement came into existence, would not suffice. On the other hand, relatively strong public policy considerations embedded in F2 law for disallowing arbitration should be respected (to the extent of not being thwarted by an anti-suit injunction)-even if the parties' preference for arbitration is clearly expressed.

Two closely related arguments support this approach. First, the injunction merely effectuates the parties' agreement to resolve all disputes through arbitration. The enjoined party, if it invokes judicial proceedings in $\mathrm{F} 2$, does something that it promised not to do. The injunction holds that party to its agreement. Second, the injunction is a particularly effective way of giving force to a principal goal of the New York Convention ${ }^{2}$-ensuring that international arbitration agreements are honored and enforced.

The opposing view rejects all (even indirect) interference with foreign legal proceedings, because it considers such interference an offense against sovereignty. The injunction opponents do not disagree that parties should be held to their agreements and that arbitration agreements should be enforced. They look instead, however, to the courts of $\mathrm{F} 2$ to make that determination, not exclusively those of F1.

If the controversy were left at this level of generality, one might wonder what all the fuss is about. So many countries have become parties to the New York

\footnotetext{
2 U.N. Convention on the Recognition and Enforcement of Foreign Arbitral Awards,
} June 10, 1958, 21 U.S.T. 2517, 330 U.N.T.S. 3 [hereinafter New York Convention]. 
Convention $^{3}$ that the Convention's support for enforcing arbitration agreements is now respected in all parts of the world. So why should F2 care if an F1 court issues an anti-suit injunction to enforce an arbitration agreement that F2 also has an obligation under the New York Convention to enforce? The court in F1 is simply protecting the pro-arbitration litigant from incurring the unnecessary and wasteful expense of litigating once again, this time in F2, to enforce the arbitration agreement. The parties presumably chose arbitration in the first place to avoid just such vexatious parallel proceedings in different national forums.

This way of looking at the problem, however, obscures the fundamental difficulty. A dispute's arbitrability is not always clear cut. Sometimes the party opposed to arbitration resorts to $\mathrm{F} 2$ courts in open breach and complete disregard of the arbitration agreement. This is the easy case, where not very much can be said against an injunction that holds a breaching party to its agreement. At other times, however, the parties take different positions on whether their underlying dispute is in fact "arbitrable"-that is, whether an arbitration agreement (or an obligation to arbitrate) binding the two parties has actually come into existence; or whether, if it did come into existence, it is valid; or whether, if it did come into existence and is valid, a particular disputed issue is within the agreement's scope. These are the three fundamental issues of "arbitrability": existence, validity, and scope of the arbitration agreement.

3 There were 142 parties as of June 1, 2007. See www.uncitral.org for the latest count. 
On these three questions, different legal systems may give different answers on the same basic set of facts. Thus F1, applying its own choice-of-law rules, might decide that " $X$ " law governs and that under that law the dispute is arbitrable. But F2, applying its own (potentially different) choice of law rules, might decide that " $Y$ " law applies and conclude that the dispute is not arbitrable. Even if both courts apply the same law, they might apply the law differently or assess the facts differently and reach different results.

With this added complexity in view, one can understand why commentators and courts might object to an F1 order that seeks to control the outcome in F2. Indeed some commentators believe that the New York Convention can be invoked as authority opposed to antiforeign-suit injunctions-even where the injunction's purpose is to enforce an arbitration agreement. The claim is not so much that the New York Convention directly regulates the issue of parallel proceedingsbecause it does not-but rather that the Convention's structure and spirit contemplate and indirectly legitimize parallel proceedings and hence that anti-foreign-suit injunctions tend to clash with the logic and harmony of the Convention regime.

The New York Convention and Anti-foreign-suit Injunctions

The anti-injunction argument proceeds as follows. ${ }^{4}$ Article II of the New York Convention deals with a state's

See Marco Stacher, You Don't Want to Go There-Antisuit Injunctions in International Commercial Arbitration, 23 ASA Bulletin, at 647-649 (2005). 
obligation to enforce an arbitration agreement. The obligation is subject, however, to two qualifications. First, under Article II(3) a court need not refer parties to arbitration if it finds that the arbitration agreement is "null and void, inoperative or incapable of being performed." The issue here is whether the dispute is "arbitrable". The court need not "refer the parties to arbitration" if it finds that the agreement is 1) non-existent or 2) invalid or 3 ) that the dispute is not within the agreement's scope. An existence question arises, for example, where one of the litigants may not be a party to the agreement (or otherwise bound by the arbitration obligation). A validity question is in issue, for example, if a party argues that the arbitration agreement is not in writing or was induced by a misrepresentation. A scope issue arises if the agreement's language may not be broad enough to include the underlying merits-based dispute. Existence, validity and scope, then, are the central issues of what I will call "ordinary arbitrability".

Second, the obligation applies only if, according the Article II(1), the arbitration agreement concerns "a subject matter capable of settlement by arbitration." This second condition-that of what I prefer to call "nonarbitrable subject matter"-could be seen as subsumed within the first ("ordinary arbitrability"), because it is simply a specific instance of an invalid arbitration agreement. Because the issue turns heavily on public policy considerations, however, it is useful to treat it separately.

Article II does not say which state's law should decide ordinary arbitrability (existence, validity, and scope). Presumably a given court will apply it's own 
choice-of-law rules to decide what law governs these issues. If the parties have specifically chosen a given state's law to govern the arbitration agreement, ${ }^{5}$ however, most choice-of-law systems will respect that choice. Thus, in this situation-the one with which I am principally concerned (where the parties have chosen the law of the seat)-most states will apply the same law in deciding ordinary arbitrability (the law of the seatbecause that law was specifically chosen by the parties). Thus, where an F1 court, interpreting and applying its own, party-chosen law, finds a dispute arbitrable and enjoins a litigant from proceeding anew in F2, it is hard to see why F2 would be especially upset. Presumably F2 would apply the same law and reach the same result as to arbitrability. F2 could hardly quarrel with F1's interpretation and application of F1's own law. The injunction merely saves the parties the additional and unnecessary expense of duplicative litigation. ${ }^{6}$

Neither party autonomy nor uniform choice of law will apply, however, for the question of non-arbitrable subject matter ("non-arbitrability"). Although Article II

$5 \quad$ Parties do not normally choose a law specifically to govern the arbitration clause. Typically, instead, they include the choice-of-law clause in a different part of the contract and intend it to apply to the entire contract, including the arbitration clause. If the parties do not include a choice-of-law clause in and for the arbitration clause itself, it seems reasonable to treat a choice-of-law clause included for the entire contract to apply as well to the arbitration clause. This is all the more so when the parties choose that same state's law as the lex arbitri (by choosing that state as the seat of the arbitration). This of course is the special case with which this essay deals-the case in which the parties place the seat in F1 and also choose F1 law to govern the arbitration agreement.

6 The parties could easily be understood to have agreed (by placing the seat in F1 and choosing F1 law) that F1 (and not F2) should decide any disputes over "ordinary arbitrability". Thus, an F1 anti-suit injunction could be seen as enforcing not only the parties' agreement to arbitrate in F1, but also their implicit agreement to resolve ordinary arbitrability questions in F1 as well. 
does not mention choice-of-law issues, Article $\mathrm{V}$, dealing with enforcement of the award, does. It provides in $\mathrm{V}(2)(\mathrm{a})$ that an award may be refused recognition and enforcement if it deals with a subject matter "not capable of settlement by arbitration under the law of that country [the enforcing country]; ${ }^{*} *{ }^{* 7}$ If one assumes, as seems reasonable-at least for the sake of consistency-that the lex fori rule of Article $\mathrm{V}$ (dealing with award enforcement) should also apply under Article II (dealing with agreement enforcement), then the Convention contemplates that courts in different states may reach different results on the issue of non-arbitrabilitydifferent results that in a sense would be legitimate.

Thus, an injunction opponent would arguepersuasively I think - that when the dispute concerns the public-policy-infused issue of non-arbitrable subject matter, the Convention contemplates legitimately different outcomes in different national legal systems. It would go against the structure and spirit of the Convention, the injunction opponent would argue, for F1 to enjoin a party from proceeding in F2, where $\mathrm{F} 2$ might consider that the subject matter has such a public impact that private ordering is excluded and the dispute is nonarbitrable. For example, the dispute could concern F2's antitrust law, and for public policy reasons F2 might deem such issues non-arbitrable. The New York Convention clearly contemplates and legitimizes such an $\mathrm{F} 2$ reaction, leaving it to $\mathrm{F} 2$ to decide when nonarbitrability applies.

One might even take this reasoning a step further (beyond the New York Convention) to argue that

7 Emphasis added. 
whenever the dispute involves matters of legitimate public policy concern in F2, F1 should not enjoin a party from proceeding in F2. Here the logic would be that "international comity" considerations are particularly strong when public policy issues are in play, and that it is particularly offensive for an F1 injunction to interfere with the safeguarding in F2 of its legitimate public policy concerns. Indeed, approving an injunction in this setting might be seen as a form of collusion between F1 and private parties to evade F2's mandatory, publicregulatory law-law that $\mathrm{F} 2$ trusts only its judges to enforce, not arbitrators.

Up to this point in the discussion I would agree with the injunction opponents. But this line of reasoningconcerning non-arbitrable subject matter-does not extend to ordinary arbitrability issues that do not raise public-policy concerns-in particular to those involving ordinary contract enforcement issues concerning the existence, validity, and scope of the arbitration agreement. On these matters it is difficult to find in the Convention any particular support for multiple parallel proceedings. The Convention seems either neutral, or, if anything, might be cited in support of a system effecting strong enforcement of an arbitration agreement-given that making arbitration agreements fully enforceable is one of the Convention's principal goals.

I believe this point comes home even more forcefully, if one applies it in the specific context I mentioned at the outset of this essay-where the parties have placed the seat of their arbitration in F1 and have chosen F1 law to govern the arbitration agreement. In most of the jurisdictions of which I am aware, such an 
agreement would provide good personal jurisdiction over both parties in $\mathrm{F} 1$ courts to enforce the arbitration agreement. $^{8}$ If the pro-arbitration litigant seises an F1 court seeking enforcement of the arbitration agreement and that court, applying its own law, finds the dispute arbitrable, why would it not be fully legitimate for the F1 court to bar the anti-arbitration litigant from forum shopping to find a court that might reach a different result (or simply to impose further litigation costs on the pro-arbitration litigant)?

Indeed, it does not seem farfetched to cite the Convention's basic agreement-enforcing policy as supporting an injunction remedy here. By choosing an F1 seat and F1 law to govern their agreement, the parties can be seen to have agreed that F1 courts should decide all questions of ordinary arbitrability. An injunction barring the arbitration opponent from proceeding in F2 merely enforces this aspect of the parties' intentions. Allowing the respondent to raise the arbitrability question anew in an F2 court (and thereby to impose on the pro-arbitration litigant the corresponding costs of such a proceeding), is just what the parties intended to avoid.

\footnotetext{
8 See, e.g., Victory Transp. Inc. v. Comisaria Gen., 336 F.2d 354, 363 (2d Cir. 1964), cert. denied, 381 U.S. 934 (1965) ("By agreeing to arbitrate in New York, where the United States Arbitration Act makes such agreements specifically enforceable, the Comisaria General must be deemed to have consented to the jurisdiction of the court that could compel the arbitration proceeding in New York."); Peter Schlosser, Antisuit injunctions zur Unterstützung von internationalen Schiedsverfahren, Recht der internationalen Wirtschaft, vol. 52. afl. 7, 486, at 491 (2006).
} 
A Forum for Strong Enforcement of an Arbitration Agreement

Consider the perspective of private parties negotiating an international transaction who want to include a reliable and fully enforceable arbitration agreement and who want to avoid parallel proceedings. Their contractual freedom is surely enhanced, if they know that a jurisdiction exists (F1) that will enjoin a parallel proceeding outside of $\mathrm{F} 1$ in breach of the arbitration agreement-at least if the seat is in F1 and F1 law applies. The parties then have the freedom to select this system of strong enforcement by drafting their agreement to place the seat in F1 and to choose F1 law to govern the arbitration agreement. This method will not allow them to evade appropriately applicable foreign mandatory law-the kind of law that defines nonarbitrable subject matter. But otherwise they can count on a strongly enforceable arbitration agreement.

If there were no such forum, might we not expect private interests dependent on global transactions to lobby governments for an arbitration law that would serve this end? Is this not how we got Article II of the New York Convention in the first place-through private interests articulating the need for a treaty regime guaranteeing the enforceability of arbitration agreements? In this sense I think it is fair to cite the New York Convention's pro-enforcement policy goal as at least not inconsistent with-and, in fact, more or less supportive of-anti-foreign-suit injunctions to enforce arbitration agreements (under the conditions discussed). 
Case Law in the US and UK Favoring Anti-foreign-suit Injunctions to Enforce Arbitration Agreements

Currently the courts of the US, and especially those of the UK, are prepared to act as strongly enforcing jurisdictions. In the US even the Second Circuit, which generally favors a restrictive approach to anti-foreign-suit injunctions, ${ }^{9}$ has been willing to issue an injunction to enforce an arbitration agreement-at least where the seat was in the US and US law governed the arbitration agreement. Although other factors played a role, the Second Circuit in Paramedics v. GE Medical Systems ${ }^{10}$ cited the strong federal policy in favor of enforcing arbitration agreements as helping to overcome "international comity" concerns and justifying an injunction. In another case, Pepsico v. Oficina Central, ${ }^{11}$ where the parties put the seat in New York but chose Venezuelan law to govern the arbitration agreement, the New York federal district court refused to enjoin a parallel proceeding in Venezuela challenging arbitrability. ${ }^{12}$ After all, the parties had chosen Venezuelan law to determine arbitrability; so it was appropriate for a Venezuelan court to be the principal

9 See Goss Int'l Corp. v. Man Roland Druckmaschinen Aktiengesellschaft, 491 F.3d 355, 359 (8th Cir. 2007) (listing the First, Second, Third, Sixth, and District of Columbia Circuits as following a "conservative approach" and the Fifth and Ninth Circuits, a "liberal approach" to anti-foreign-suit injunctions).

10 See Paramedics Electromedicina Comercial, Ltda. v. GE Medical Sys. Info. Techs, Inc., 369 F.3d 645 (2d Cir. 2004) (seat was in Miami and New York law applied, see 2003 WL 23641529 (S.D.N.Y., 2003)).

11 Pepsico, Inc v. Oficina Central de Asesoria Y Ayuda Tecnica, C.A., 945 F.Supp. 69 (S.D.N.Y. 1996).

12 See also, LAIF X SPRL v. Axtel, 390 F.3d 194 (2d Cir. 2004) (refusal to enjoin parallel proceedings in Mexico where arbitrability would be decided under Mexican law). 
interpreter of what the outcome should be under its own law.

Two recent UK cases, Through Transport ${ }^{13}$ and West Tankers, ${ }^{14}$ are especially illustrative of the approach I am urging. Through Transport involved loss of cargo shipped from India through Finland to Moscow. New India, the cargo insurer, paid and was subrogated to cargo's claim against the carrier, but the carrier was insolvent. All was not lost, however, because the carrier had liability insurance, and Finland had enacted a direct action statute allowing a creditor to bypass the insolvent debtor and sue the liability insurer directly. This is what New India elected to do, by suing in Finland on a theory that the loss-causing event occurred there and that Finnish courts thus had good jurisdiction.

New India had a particular reason for suing in Finland under the Finnish direct action statute rather than in the UK under the equivalent UK statute. The carrier's liability insurance contract contained a "pay to be paid" clause obligating the insurer to pay only if the insured had previously paid on a covered claim (an indemnity contract). The "pay to be paid" clause was enforceable in English law but arguably not so under Finnish law. The Finnish statute contained anti-evasion provisions that potentially voided both the "pay to be paid" clause and the arbitration clause (on a theory of

\footnotetext{
13 Through Transp. Mut. Ins. Ass'n v. New India Assurance Ass'n, [2005] 1 Lloyd's Rep. 67 ; [2005] 1 All E.R. (Comm) 715; 2004 WL 2714108 (CA (Civ Div)).

14 West Tankers Inc v. Ras Riunione Adriatica di Sicurta, [2005] 2 Lloyd's Rep 257; [2005] 2 All E.R. (Comm) 240; 2005 WL 699582 (QBD (Comm Ct)) (affirmed by the House of Lords, but the House of Lords referred to the European Court of Justice the question of the legality of the anti-suit injunction under possibly applicable EU law, 20007 WL 504700; see note 15 infra).
} 
non-arbitrable subject matter). Thus, Finnish public policy seemed to offer New India a chance at recovery for a loss caused in Finland.

The liability insurance contract (including the arbitration clause) was governed by English law and provided for arbitration in London. Not liking its prospects in Finland, Through Transport, the liability insurer, sued New India in the UK seeking arbitration and an injunction barring New India from continuing with the Finnish action. The Court of Appeal ordered arbitration, reasoning that under English law (which it found applicable) New India could not enforce the claim stemming from the liability insurance contract without honoring that contract's arbitration clause once Through Transport invoked it.

At the same time the court refused to enjoin New India from continuing with its Finnish action. The court reasoned that by suing in Finland New India did not "breach" the arbitration agreement, to which it was not a party. Its obligation to arbitrate came about through operation of law, not through its specific agreement to arbitrate. But the court also stressed the role of Finnish public policy. The Finnish law was not entirely clear, but it was certainly arguable that Finnish public policy stemming from the anti-evasion provisions of its direct action statute would annul both the "pay to be paid" and arbitration clauses. The importance of this public policy element becomes clearer when one compares the outcome in the West Tankers case.

West Tankers is an analogous case but with a crucial difference and an opposite result on the 
injunction issue. There the oil-tanker carrier rammed and damaged the charterer's wharf in Italy. Erg, the wharf insurer, paid and was subrogated to the wharf owner/charterer's claim. Erg sued West Tankers, the ship owner, in Italy on a tort theory for damage to the wharf. West Tankers, preferring arbitration, sued Erg in the UK to enforce the arbitration clause and for an injunction ordering Erg to dismiss its Italian action. The charterparty, under which the oil tanker operated, provided for English law and London arbitration. The key questions were whether Erg was bound by the arbitration provisions of the charterparty, to which it was not a party, and whether UK or Italian law should decide that issue.

The court ruled that UK law applied, that Erg was required to honor the arbitration clause, and that the clause was broad enough to include the tort claim for wharf damage (governed substantively by Italian law). In dictum the court also concluded that Italian law would have reached the same result. Under neither law, however, was Erg a formal party to the arbitration agreement. Therefore Erg did not breach that agreement by suing in Italy-which was one of the prominent reasons the Through Transport court gave for not enjoining prosecution of the parallel proceeding in that case. Still, having decided the "ordinary arbitrability question" in favor of arbitration, the West Tankers court enjoined Erg from continuing with the Italian proceeding. ${ }^{15}$ Although the court noted that the Italian

15 On appeal the House of Lords agreed with the Commercial Court's decision to
grant the injunction, but referred to the European Court of Justice (ECJ) the question
whether the Turner v. Grovit principle would apply to disallow the anti-suit injunction.
The Turner v. Grovit principle prohibits an EU member state from enjoining the
prosecution of a claim in another EU member state. See Turner v. Grovit, C-159/02, 
court might well object to the UK anti-suit injunction and refuse to enforce it, none of the litigants claimed that Italian public policy was involved in any way or that the subject matter was non-arbitrable in Italy. ${ }^{16}$

Although the West Tankers court did not distinguish Through Transport on the specific ground for which I am arguing-the presence or absence of public policy concerns in the parallel jurisdiction-I believe that distinction provides a good explanation for the conflicting outcomes. In neither case did filing a claim in the parallel jurisdiction constitute a breach of the arbitration agreement. So this factor cannot explain the different outcomes. In Through Transport-where the injunction was refused-the Court of Appeal noted the importance of not interfering with parallel prosecution of the plausible claim that Finnish mandatory law (public policy) would void the "pay-to-be-paid" clause (and even the arbitration clause) under the Finnish direct action

Judgment of the European Court of Justice of April 27, 2004. Turner v. Grovit was based, however, on considerations stemming from the EU's jurisdiction and judgments regulation (Council Regulation (EC) No. 44/2001 of 22 December 2000 on jurisdiction and the recognition and enforcement of judgments in civil and commercial matters OJ L 12, 16.1.2001, p. 1-23 (the so-called "Brussels Regulation")), which is not applicable to "arbitration". The preliminary reference to the ECJ in West Tankers is still pending before the ECJ. The West Tankers case is likely to be best known in the future for the answer the ECJ gives to this important question.

16 For a similar result, see "Epsilon Rosa" (No. 2) [2002] 2 Lloyd's Rep. 701 (Com. Ct.), where, after complex analysis, the UK court concluded that the bill of lading cross-referenced and hence incorporated the charterparty arbitration clause (choosing UK law and a UK arbitral seat). The court acknowledged that the parallel proceeding in Poland might not have reached the same result on the arbitrability question, but still enjoined that proceeding. Note that the Polish proceeding involved an ordinary arbitrability issue (existence of an arbitration agreement), not questions of non-arbitrable subject matter or other Polish public policy concerns. The Epsilon Rosa court found that language in the bill of lading clearly put the cargo claimant on notice that the referenced charterparty's arbitration clause and applicable law were to be incorporated. Thus, the result accords with the theory that the parties had agreed upon the UK as the forum to resolve ordinary arbitrability issues, since the charterparty clause implicitly so provided. 
statute. In West Tankers-where the injunction issuedthere were no public policy questions at stake in the enjoined Italian proceeding.

One could think of other patterns where this public policy distinction would come into play. For example, suppose a Belgian distributor agrees to distribute an American manufacturer's products in Belgium, and the parties include an arbitration clause, choosing English law to govern the clause, and arbitration in London. Under Belgian mandatory law a Belgian distributor's claim for an extended termination period and compensation (both provided for in Belgian statutory law) is non-arbitrable subject matter. ${ }^{17}$ If the parties fall into dispute over termination of the agreement, a British court would probably order arbitration, but it should not enjoin the Belgian party from pursuing its claim in Belgian courts under Belgian mandatory law. Under Belgian law-designed to protect Belgian distributorsthe Belgian distributor's claim is non-arbitrable subject matter. It would constitute an unsupportable disturbance of international comity (perhaps triggering a counter antisuit injunction) for a British court to enjoin a Belgian distributor from suing in a Belgian court for protection under fully applicable Belgian public policy.

\section{Conclusion}

In summary I have argued in favor of a proarbitration use of anti-foreign-suit injunctions to enforce

\footnotetext{
17 See Audi-NSU Auto Union A.G. v. S.A. Adelin Petit \& Cie, Cour de Cassation (1979), 5 Yearbk. Comm. Arb'n 257 (1980). For the major provisions of the Belgian statute, which are quoted in English translation and discussed, see Audi-NSU Auto Union A.G. v. S.A. Adelin Petit \& Cie, Cour d'appel de Liege, 4 Yearbk. Comm. Arb'n 254, 255-56, nn. 2, 3 and 7 (1979)).
} 
arbitration agreements where the injunction would not interfere with legitimate public policy interests (making the dispute non-arbitrable) in the parallel jurisdiction. Where the dispute involves ordinary issues of arbitrability (existence, validity, and scope) and the parties have chosen an arbitration seat and that seat's law to govern the arbitration agreement, a court at the seat should be free to enforce the agreement and enjoin the respondent from breaching it through parallel litigation elsewhere. Issuance of an anti-foreign-suit injunction in this situation should not be seen as infringing international comity (much less, international law).

This result seems fair and reasonable; indeed I believe it accords with the basic policy of the New York Convention and with what global economic actors would want to have available for their dispute settlement arrangements. It also seems conceivable that the availability of strong enforcement remedies for arbitration agreements in the US and UK (and other common-law jurisdictions) will make these venues all the more attractive to parties seeking a reliable and cost-saving seat of arbitration. If that prediction turns out to be accurate, might we not expect the arbitration bar itself in countries now opposed to anti-suit injunctions to align themselves with this essay's arguments and to urge their own courts to employ this remedy in suitable cases ${ }^{18}$-or risk a decline in their arbitration business.

\footnotetext{
18 Schlosser makes essentially this point, see Schlosser, supra note 8, at 487, as does Lord Hoffman in his opinion for the House of Lords in West Tankers, supra note 14 , at $20-21$.
} 